Jurnal Visionida, Volume 4 Nomor 2 Desember 2018

\title{
ANALISIS PENGENDALIAN PERSEDIAAN UNTUK MEMINIMALISASI BIAYA PADA BAHAN KEMASAN BOTOL 70 ML 8 GRAM DI PT. MILKO BEVERAGE INDUSTRY BOGOR
}

\author{
STOCK CONTROL ANALYSIS FOR COST REDUCING OF BOTTLE PACKAGING \\ MATERIAL WITH SIZE 70 ML 8 GRAM AT PT. MILKO BEVERAGE INDUSTRY BOGOR
}

\author{
Aah Solahuddin ${ }^{1)}$; Titiek Tjahja Andari ${ }^{2)}$ \\ Progam Management Studies Faculty of Economics, University of Djuanda Bogor \\ Email : ${ }^{1)}$ ocha.solahudin@yahoo.co.id; titiek_tjahja@yahoo.com ${ }^{2)}$
}

\begin{abstract}
PT. Milko Beverage Industry is a local company producing milk and dairy beverage products. This research discusses control of bottled $70 \mathrm{ml} 8$ gram supplyin 2016. Along with this research provides and recommends the most optimal inventory control method for the company's current cost. by comparing the company's calculation method with MRP method of and EOQ techniques. The recommended calculation resultis analyzed by sensitivity analysis to find of the result towards inflation of Bank Indonesia. The study result recommends that LFL technique of MRP method provides optimal and most cost-effective results compared to the company's method calculation and EOQ technique of MRP, and the result of the sensitivity analysisof that method has no effect on inflation.
\end{abstract}

Keyword: Supply Control, Material Requirement Planning (MRP) Method, and Sensitivity Analysis

\begin{abstract}
ABSTRAK
PT. Milko Beverage Industry merupakan perusahaan lokal pada industri minuman susu. Penelitian ini menjelaskan pengendalian persediaan kemasan botol $70 \mathrm{ml} 8$ gram tahun 2016 . Bersamaan dengan penelitian ini memberikan dan merekomendasikan metode persediaan paling optimal biayanya bagi perusahaan, dengan membandingkan metode perhitungan perusahaan dan metode perencanaan kebutuhan material (MRP) Lot For Lot (LFL) dan Economic Order Quantity (EOQ). Perhitungan yang direkomendasikan akan dianalisisa dengan analisis sensitivitas untuk mengetahui hasil terhadap inflasi Bank Indonesia. Hasil penelitian merekomendasikan bahwa MRP LFL memberikan solusi optimal dan paling hemat biaya dibandingkan dengan perhitungan perusahaan dan MRP teknik (EOQ), dan hasil analisis sensitivitas menghasilkan metode tersebut tidak berpengaruh terhadap inflasi.
\end{abstract}

Kata Kunci : Pengendalian Persediaan, Metode Perencanaan Kebutuhan Material (MRP) dan Analisis Sensitivitas 


\section{PENDAHULUAN}

Persediaan merupakan aset yang memegang fungsi krusial dalam operasi perdagangan maupun industri manufakur. Perusahaan harus melakukan pengendalian persediaan dan memiliki kapabilitas dalam mengantisipasi tantangan terkait persediaan manajemen untuk mencapai target dan hasil akhir yang dapat meminimalisasi biaya perusahaan (Yamit, 2002). Dalam sistem manufaktur maupun perdagangan adanya persediaan dapat meningkatkan biaya. Kesalahan sering terjadi bila persediaan dengan jumlah banyak, yang berakibat modal mengendap pada persediaan yang disimpan, tetapi bila stock persediaan tidak begitu banyak akan memberikan kesempatan bagi perusahaan untuk mendapatkan laba maksimal.

Jumlah persediaaan yang ditetapkan dari perhitungan yang tidak sesuai dengan kebutuhan dapat menyebabkan kelebihan ataupun kekurangan dalam jumlah besar. Hal tersebut seringkali dihindari oleh perusahaan karena akan menimbulkan besarnya biaya modal pada persediaan. Indrajit dalam Wawan (2008) menyatakan bahwa biaya penyimpanan untuk persediaan setiap periodik tahunan biasanya mencapai 20 persen s/d 40 persen dari nilai barang, sehingga pengendalian suatu persediaan sangat esensial dalam organisasi industri.

PT. Milko Beverage Industri merupakan perusahaan manufaktur yang memproduksi susu dalam bentuk kemasan yang berdiri pada tahun 2005. Perusahaan memproduksi 5 (lima) jenis produk minuman mengandung susu untuk anak-anak salah satu produk andalannya adalah Milky Moo Susu $70 \mathrm{ml}$. Dalam hal pengemasan produk, PT. Milko menggunakan 2 (dua) jenis kemasan yaitu kemasan primer dan sekunder. Kemasan primer meliputi botol, sedotan dan allu cap foil sebagai penutup botol sedangkan kemasan sekunder meliputi karton dan shring label.

PT. Milko mengkategorikan botol sebagai persediaan bahan kemasan utama. Sebagai bahan kemasan utama, botol sangat memerlukan perhatian khusus terkait pengendaliaan dalam persediaannya agar jalannya produksi tidak terganggu.

Persediaan bahan kemasan botol $70 \mathrm{ml} 8$ gram pada tahun 2016 dikatakan memiliki nilai yang banyak sehingga menyebabkan biaya persediaan sangat besar. Hal tersebut dapat dilihat dalam Tabel 1 pembelian, pemakaian serta persediaan akhir pada tahun 2016:

Tabel 1. Modal Pembelian dan Persediaan Akhir Botol 70 ml 8 gram Tahun 2016

\begin{tabular}{|c|c|c|c|c|c|c|c|}
\hline \multirow[t]{2}{*}{ No } & \multirow[t]{2}{*}{ Bulan } & \multicolumn{2}{|c|}{ Pembelian } & \multicolumn{2}{|c|}{ Pemakaian } & \multicolumn{2}{|c|}{ Persediaan Akhir } \\
\hline & & Pes & $\mathbf{R}_{\mathbf{P}}$ & Pes & $\mathbf{R}_{\mathbf{P}}$ & Pcs & $\mathbf{R}_{\mathbf{P}}$ \\
\hline 1 & Januari & 3.961 .442 & 891.324 .450 & 4.395 .600 & 989.010 .000 & 1.007 .000 & 226.575 .000 \\
\hline 2 & Februari & 4.915 .860 & 1.106 .068 .500 & 3.145 .860 & 707.818 .500 & 2.777 .000 & 624.825 .000 \\
\hline 3 & Maret & 4.014 .600 & 903.285 .000 & 5.085 .600 & 1.144 .260 .000 & 1.706 .000 & 383.850 .000 \\
\hline 4 & April & 3.895 .060 & 876.388 .500 & 3.288 .060 & 739.813 .500 & 2.313 .000 & 520.425 .000 \\
\hline 5 & Mei & 2.592 .720 & 583.137 .000 & 4.320 .720 & 972.162 .000 & 584.000 & 131.400 .000 \\
\hline 6 & Juni & 5.577 .700 & 1.254 .982 .500 & 4.319 .700 & 971.932 .500 & 1.842 .000 & 414.450 .000 \\
\hline 7 & Juli & 4.331 .980 & 974.695 .500 & 4.048 .980 & 911.932 .500 & 2.125 .000 & 478.125 .000 \\
\hline 8 & Agustus & 1.657 .140 & 372.856 .500 & 2.527 .140 & 568.606 .500 & 1.255 .000 & 282.375 .000 \\
\hline 9 & September & 4.033 .400 & 907.515 .000 & 3.398 .400 & 764.640 .000 & 1.890 .000 & 425.250 .000 \\
\hline 10 & Oktober & 5.013 .620 & 1.128 .064 .500 & 5.434 .620 & 1.222 .789 .500 & 1.469 .000 & 330.525 .000 \\
\hline 11 & November & 5.136 .580 & 1.155 .730 .500 & 5.540 .580 & 1.246 .630 .500 & 1.065 .000 & 239.625 .000 \\
\hline 12 & Desember & 7.720 .760 & 1.737 .171 .000 & 6.881 .760 & 1.548 .396 .000 & 1.904 .000 & 428.400 .000 \\
\hline & Total & 52.849 .862 & 11.891 .218 .950 & 52.387 .020 & 11.787 .079 .500 & 19.937 .000 & 4.485 .825 .000 \\
\hline
\end{tabular}

Sumber : PT. Milko Beverage Industry, 2016

Tabel 1 menjelaskan terjadi pembelian dengan nilai sebesar Rp 11.891.218,950.- dan kemasan botol sebanyak 52.849.862 pcs persediaan akhir sebanyak 19.937 .000 pcs. 
nilai sebesar Rp4.485.825.000,- berdasarkan data tersebut, biaya modal perusahaan cukup besar sehingga perputaran modal menjadi terhambat dan mengendap pada jumlah persediaan tidak bergerak. Besarnya biaya tersebut dikarenakan pembelian berdasarkan target produksi yang ditetapkan, padahal kenyataannya pencapaian produksi dibawah target hanya 71,48 persen. Sehingga perlu dilakukan alternatif strategi pengendalian bahan kemasan untuk persediaan botol ukuran $70 \mathrm{ml} 8$ gram yang disesuaikan dengan kemampuan perusahaan secara akurat dan efisisien. Begitu pentingnya pengendalian persediaan terhadap minimalisasi biaya pada perusahaan, maka tujuan dilakukan riset ini yaitu untuk mengetahui pengendalian pada persediaan bahan kemasan botol ukuran $70 \mathrm{ml}$ 8 gram, untuk mengetahui persediaan bahan kemasan botol ukuran $70 \mathrm{ml} 8$ gram dengan menggunakan MRP teknik EOQ dan teknik Lot For Lot dan untuk mengetahui dampak perubahaan harga terhadap optimalisasi pengawasan persediaan pada bahan kemasan botol ukuran $70 \mathrm{ml} 8$ gram di PT. Milko Beverage Industry.

\section{MATERI DAN METODE}

\section{Manajemen Operasional}

Manajemen operasional menurut Heizer dan Rander (2006) adalah merubah input menjadi output untuk menambah nilai suatu produk .

\section{Persediaan}

Persediaan menurut Assauri (2008) adalah merupakan sejumlah bahan-bahan yang dibutuhkan untuk kegiatan produksi. Pada dasarnya persediaan memberikan kelancaran terhadap keberlangsungan produksi perusahaan. Persediaan merupakan elemen modal kerja sehingga diperlukannya pengelolaan yang baik dalam pengelolaannya.

Jenis-jenis persediaan berdasarkan fungsinya (Rangkuti;2007) meliputi :
1. Fungsi Decoupling merupakan persediaan perusahaan untuk memenuhi permintaan langganan.

2. Fungsi Economic Lot Sizing yaitu persediaan yang memperhatikan optimalisasi biaya atau potongan dari pembelian, biaya angkut unitnya sehingga menjadi lebih murah.

3. Fungsi antisipasi yaitu bila terjadi naik turun permintaan, perusahaan membuat estimasi ramalan berdasar pengalaman atau data di masa lalu.

Rangkuti (2007) mengemukakan biaya atau pengeluaran yang timbul dari adanya persediaan yaitu:

1. Biaya penyimpanan.

2. Biaya pemesanan.

3. Biaya penyiapan merupakan biaya yang muncul jika bahan/barang tidak dibeli oleh perusahaan, tetapi diproduksi oleh perusahaan tersebut.

4. Biaya habis atau kekurangan bahan.

\section{Pengendalian Persediaan}

Menurut Herjanto (2008) pengendalian adalah prosedur pengendalian persediaan yang harus dicadangkan, kapan dan berapa besarnya pesanan yang harus dilakukan.

Menurut Assauri (2008) tujuan pengendalian pada persediaan adalah:

a. Memperhatikan jumlah persediaan agar terhindar dari kehabisan bahan sehingga tidak menghalangi jalannya produksi.

b. Menghindari jumlah persediaan yang berlebihan untuk menghindari biaya-biaya yang akan timbul.

c. Menghindari pembelian skala kecil untuk menghindari biaya pemesanan.

Menurut Handoko (2012) ada beberapa metode yang dapat dilakukan untuk mengendalian persediaan yaitu:

1. Metode pengendalian statistik (Statistical Inventory Control) yaitu metode dengan menggunakan perhitungan matematika serta statistik yang dijadikan alat utama 
sebagai solusi pada masalah kuantitatif persediaan. Metode ini akan memberikan solusi optimal dengan menentukan besarnya persediaan pada pemesanan dinamis, titik pesanan kembali dan persediaan pengaman.

2. Metode persediaan Just In Time ( JIT) yaitu metode yang dikembangkan dan dipublikasikan oleh Taichi Ohno dan koleganya di perusahaan Toyota Motor di Jepang, dan dikenal luas tahun 1978. Sistem ini menekankan pada material menjadi suatu bagian aktif pada sistem produksi serta tidak boleh menimbulkan suatu masalah persediaan yang akhirnya bisa mengakibatkan timbulnya biaya persediaan. Metode JIT persediaan seminimum mungkin menjaga secara tepat berlangsungnya proses produksi. Bahan/barang tersedia dalam waktu dan jumlah yang tepat dan cepat saat diperlukan dalam produksi dengan memperhatikan spesifikasi/mutu yang dikehendaki.

3. Metode perencanaan kebutuhan material (MRP) yaitu salah satu sistem perencanaan dari penjadwalan kebutuhan material untuk produksi yang dilakukan ketika suatu bahan harus dipesan/diorder oleh perusahaan kesupplier saat persediaan ditangan sudah mulai berkurang atau ketika produksi suatu bahan akan dimulai untuk memenuhi pesanan dan kepuasan pelanggan dengan leadtime tertentu (Heizer dan Render; 2005). Sistem ini menggunakan ukuran batch/lot saat barang tersebut tersedia untuk proses produksi.

Ada beberapa teknik dalam sistim MRP untuk menentukan ukuran LOT. Berikut metode dalam Material Requirement Planning (MRP) menurut Herjanto (2008) yaitu:

1. MRP teknik Economic Order Quantity (EOQ). Pada EOQ, tingkat ekonomis diperoleh pada saat biaya pemesanan (set up cost) sama dengan biaya penyimpanan (holding cost). Tetapi jika lot tersebut jumlahnya besar, biaya pemesanan nilainya kecil tetapi biaya penyimpanan besar. Sebaliknya jika jumlah lot kecil/sedikit maka terjadi biaya pemesanan nilainya akan naik tetapi biaya penyimpanan menjadi lebih sedikit.

2. MRP teknik dengan Lot For Lot (LFL). Metode ini dikenal sebagai suatu metode dengan persediaan yang minimal, penyediaan berdasarkan suatu ide/pemikiran terhadap persediaan, memproduksi sesuai dengan keperluan produksi, persediaan diusahakan seminimalkan mungkin. Jumlah pemesanan yang sesuai pada jumlah sebenarnya diperlukan hanya ukuran lot saja yang menghasilkan biaya persediaan yang tersimpan sangat kecil, yang menyebabkan besarnya biaya terjadi pada biaya pemesanan (Herjanto; 2008).

3. Analisis Sensitivitas yaitu analisis yang dilakukan terhadap penyelesaian permasalahan yang telah diperoleh sebelumnya (Bernadus, Ferdinan dan Umanto (2012). Hal ini dilakukan karena terjadinya perubahan yang disebabkan lingkungan yang dinamis, seperti perubahan harga bahan baku, permintaan konsumen/produksi yang berfluktuasi, pergantian mesin, kenaikan biaya produksi, perubahan kebijakan pemerintah dan lainlain. Analisis tersebut memberikan suatu informasi maupun keputusan untuk menanggapi perubahan tanpa harus melakukan perhitungan kembali dari awal. Dania et al (2005) mengemukakan bahwa estimasi dinyatakan sensitif apabila prosentase kenaikan biaya persediaan besarnya 30 persen atau lebih sehingga perlu diadakan perhitungan ulang.

\section{Kerangka Pemikiran}

Pengendalian terhadap persediaan bahan kemasan merupakan sesuatu yang 
esensial, karena bahan kemasan merupakan elemen yang mendukung kelancaran proses produksi. Kegiatan pengendalian terhadap persediaan bahan kemasan berhubungan dengan kegiatan pengadaan bahan sesuai kebutuhan dengan biaya minimal yaitu meliputi pembelian bahan, penyimpanan dan pemeliharaan bahan, pengaturan pengeluaran bahan dan menjaga agar jumlah persediaan optimal.

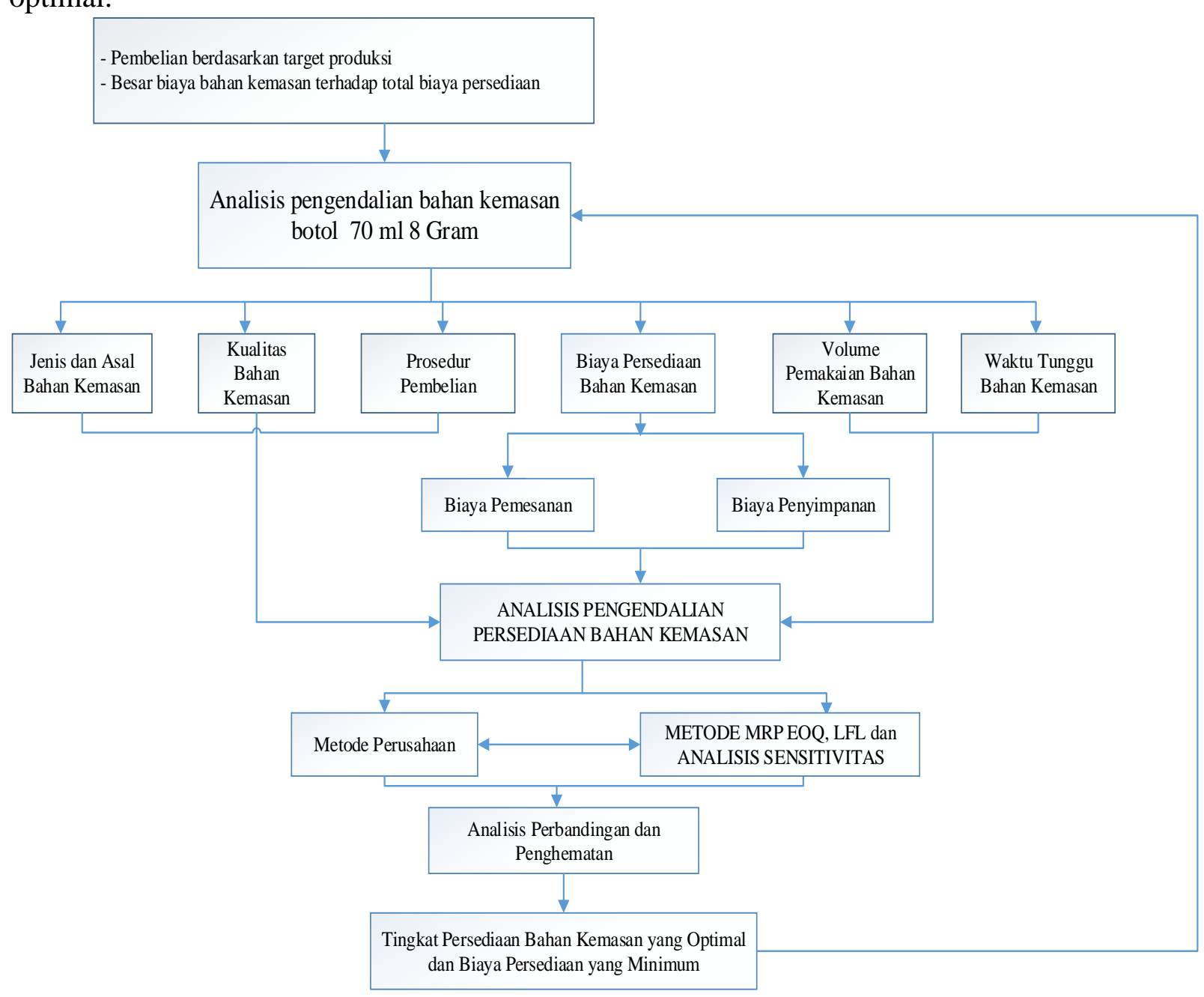

\section{Gambar 1. Kerangka Pemikiran}

\section{Desain Penelitian}

Penelitian ini didesain sebagai penelitian deskriptif yang bersifat kuantitatif karena penelitian ini berkaitan dengan objek penelitian yaitu dengan mengumpulkan keterangan-keterangan terkait data perusahaan
Pengendalian terhadap persediaan kemasan ini haruslah memperhatikan biaya dari pemesanan, biaya simpan bahan dan pemakaian bahan kemasan dalam produksi.

Secara umum, bagan dari kerangka pemikiran adalah :

yang disesuaikan dengan maksud penelitian. Penelitian dilakukan dengan menganalisis penerapan Material Requirement Planning (MRP) menggunakan 2 (dua) teknik yaitu Economic Order Quantity dan Lot for Lot. Hasil yang didapat kemudian dianalisis dan dikomparasikan dengan metode yang 
digunakan perusahaan dalam hal besarnya biaya persediaan untuk mendapatkan alternatif model yang sesuai, sehingga pengendalian dari bahan baku dapat dilakukan dengan efisien. Selain itu juga hasil perhitungkan akan dianalisis dengan analisis sensitivitas yaitu untuk menganalisis perubahan harga pada saat itu. Adapun Objek penelitian adalah bahan kemasan botol $70 \mathrm{ml} 8$ gram sebagai kemasan produk Milky Moo Susu $70 \mathrm{ml}$. Pengumpulan data diperoleh melalui Data primer dengan cara pengamatan terhadap objek penelitian secara langsung dan wawancara pada bagianbagian tertentu di perusahaan, serta data sekunder melalui laporan-laporan terutama bagian PPIC (Production Planning and Inventory Control), pembelian (Purchasing) di antaranya adalah laporan bulanan dan tahunan perusahaan.

\section{Metode Analisis Data}

Data yang didapat mengenai sistem pengolahan bahan kemasan akan dianalisis secara kuantitatif dan kemudian akan diuraikan dalam bentuk deskriptif. Dalam melakukan analisis, dengan menggunakan program komputer, data tersebut ditabulasikan secara matematis kemudian dibandingkan untuk mencari alternatif metode yang sesuai untuk diterapkan agar sesuai dengan kondisi perusahaan. Dalam menganalisis pengendalian persediaan, maka langkah pertama yang ditempuh yaitu mengidentifikasi keadaan perusahaan dalam pengendalian pada persediaan bahan kemasan, memperhatikan kebijakan-kebijakan perusahaan untuk produksi dan pembelian bahan kemasan, cara pemesanan dan besar pesanan selama ini. Perlu juga diperhatikan, kapasitas penyimpanan dan pencatatan bahan kemasan yang dilakukan. Langkah selanjutnya adalah menentukan bahan kemasan pokok perusahaan, karena bila melakukan pengendalian terhadap persediaan secara otomatis telah melakukan pengendalian terhadap biaya.

\section{PEMBAHASAN}

PT. Milko merupakan perusahaan minuman susu siap minum. Produk minuman susu yang keluarkan oleh mesin produksi langsung masuk ke dalam botol HDPE. Bahan kemasan tersebut memiliki jenis HDPE marlek 6007, tipe ini dipilih karena plastik $H D P E$ yang tahan panas sampai dengan $121^{\circ} \mathrm{c}$. Kebutuhan botol kemasan tersebut setiap harinya cukup banyak untuk memproduksi milky moo $70 \mathrm{ml}$. PT. Milko memiliki 4 (empat) supplier yang mensupplai bahan kemasan tersebut. Harga botol sebesar Rp225,-/pcs konstan setiap periodenya. Pengiriman botol ke PT. Milko dengan menggunakan kemasan dengan isi sebanyak 200 pcs perbag dengan pengiriman rata-rata setiap supplier mengirimkan dengan jumlah sebanyak 220.000-225.000 pcs persetiap kali pengiriman. Apabila pengiriman 4 (empat) supplier tersebut bersamaan waktunya maka total pengiriman sebanyak 900.000 pcs perhari, hal tersebut berdampak terhadap area dan palet sebagai alas penyimpanan yang tidak sesuai kapasitas gudang yang terbatas.

\section{Pengendalian Terhadap Persediaan Bahan Kemasan Botol 70 ml 8 gram}

Pengendalian bahan kemasan botol ukuran $70 \mathrm{ml}$ pada PT. Milko belum tertata dengan baik, hal tersebut terlihat pada sistem pengadaan bahan kemasan yang hanya dengan melihat kondisi persediaan di gudang. Pembelian bahan kemasan juga berdasar pada target produksi yang ditetapkan oleh perusahaan, padahal realisasi produksi terhadap hasil produksi rata-rata produksi setiap bulannya tidak tercapai dengan rata-rata pencapaian hanya sebesar 71,48 \% dari target yang ditetapkan oleh perusahaan. Timbulnya persediaan bahan kemasan di perusahaan tersebut disebabkan jumlah persediaan yang banyak di gudang sebagai akibat dari 
pencapaian produksi yang tidak tercapai. Selain itu disebabkan oleh perbedaannya pemakaian yang bervariasi setiap bulannya. Pengadaaan bahan kemasan akan dilakukan apabila persediaan didalam gudang telah habis terpakai sekitar 60-70 persen atau apabila bahan baku tersisa hanya 30-40 persen.

\section{Biaya Persediaan}

Biaya persediaan terdiri dari biaya pesanan dan biaya penyimpanan.

\section{Biaya Pemesanan}

Biaya pemesanan adalah biaya yang harus dikeluarkan perusahaan untuk memesan bahan kemasan sampai bahan tersebut diterima oleh perusahaan. PT. Milko mengklasifikasikan biaya pemesanan terdiri biaya administrasi dan biaya untuk bongkar muat (transportasi). Besaran biaya administrasi, biaya untuk bongkar muat dan transportasi sebesar 1 (satu) persen dari nilai pengiriman barang dalam 1 (satu) mobil yaitu dari nilai nominal pengiriman barang sebesar Rp 50.000.000,- .Komponen biaya pesanan dijelaskan pada tabel 2 yaitu:

Tabel 2. Komponen Biaya Pemesanan Botol 70 ml 8 gram Tahun 2016

\begin{tabular}{ll}
\hline Jenis biaya & $\begin{array}{l}\text { Biaga Pemesanan } \\
\text { (Rpppesanan) }\end{array}$ \\
\hline Biaya Administrasi & 50.000 \\
Biaya Bongkar MuatBarang, transpootasi & 450.000 \\
\hline Total & 500.000 \\
\hline
\end{tabular}

Sumber: PT. Milko Beverage Industry, 2017

Tabel 2 menjelaskan besarnya pengeluaran biaya sebesar Rp 500.000,terdiri biaya administrasi, biaya untuk bongkar muat dan transportasi. Semua biaya tersebut ditanggung perusahaan untuk memesan barang kemasan botol ukuran $70 \mathrm{ml} 8$ gram.

Tabel 4. Perhitungan Biaya Persediaan Perusahaan Tahun 2016

\section{Biaya Penyimpanan}

Biaya penyimpanan adalah pengeluaran biaya perusahaan terkait persediaan barang. PT. Milko mengklasifikasikan biaya penyimpan meliputi biaya penyusutan gedung sebesar 10 (sepuluh) persen dan biaya pemeliharan gudang sebesar 10 (sepuluh) persen dari nilai harga barang persediaan. Komponen biaya penyimpanan perusahaan akan ditampilkan pada tabel 3 :

\section{Tabel 3. Komponen Biaya Penyimpanan Botol 70 ml 8 gramTahun 2016}

\begin{tabular}{ll}
\hline Jenis Biaya & $\begin{array}{l}\text { Biaya Penyimpanan } \\
\text { (Rp/pes/thn) }\end{array}$ \\
\hline Biaya Penyusutan Gudang & 22,5 \\
Biaya Pemeliharaan Gudang & 22,5 \\
\hline Total & 45 \\
\hline
\end{tabular}

Sumber: PT. Milko Beverage Industry, 2017

Berdasarkan Tabel 3 dapat dilihat total biaya penyimpanan tahun 2016, perusahaan mengeluarkan biaya pertahun perunit persediaan Rp 45,-

Perhitungan biaya untuk persediaan dapat diketahui dari biaya pembelian, biaya pesanan dan biaya penyimpanan. Biaya pembelian bahan kemasan didapat dari jumlah pembelian dikali harga pembelian persatuan. Biaya pemesanan bahan kemasan perbulan didapat dari biaya pemesanan dikali dengan frekuensi pemesanan tiap bulannya. Biaya peyimpanan bahan kemasan perbulan didapat dari perkalian antara jumlah persediaan rata-rata tiap bulannya dengan biaya penyimpanan perbulannya. Berikut perhitungan biaya untuk persediaan pada tabel 4 yaitu: 


\begin{tabular}{|c|c|c|c|c|c|c|c|c|}
\hline $\begin{array}{l}\mathbf{N} \\
\mathbf{0}\end{array}$ & Bulan & $\begin{array}{c}\text { Pembelian } \\
(p c s)\end{array}$ & $\begin{array}{l}\text { Frek } \\
\text { (kali) }\end{array}$ & $\begin{array}{c}\text { Rata-Rata } \\
\text { Persediaan } \\
\text { (pcs) }\end{array}$ & $\begin{array}{c}\text { Biaya } \\
\text { Pembelian (Rp) }\end{array}$ & $\begin{array}{c}\text { Biaya } \\
\text { Pemesanan } \\
\text { (Rp) }\end{array}$ & $\begin{array}{c}\text { Biaya } \\
\text { Penyimpanan } \\
\text { (Rp) }\end{array}$ & $\begin{array}{l}\text { Total Biaya } \\
\text { (Rp) }\end{array}$ \\
\hline 1 & Januari & 3.961 .442 & 1 & 1.224 .079 & 891.324 .450 & 500.000 & 55.083 .555 & 55.583 .555 \\
\hline 2 & Februari & 4.915 .860 & 4 & 1.892 .000 & 1.106 .068 .500 & 2.000 .000 & 85.140 .000 & 87.140 .000 \\
\hline 3 & Maret & 4.014 .600 & 2 & 2.241 .500 & 903.285 .000 & 1.000 .000 & 100.867 .500 & 101.867 .500 \\
\hline 4 & April & 3.895 .060 & 1 & 2.009 .500 & 876.388 .500 & 500.000 & 90.427 .500 & 90.927 .500 \\
\hline 5 & Mei & 2.592 .720 & 2 & 1.448 .500 & 583.137 .000 & 1.000 .000 & 65.182 .500 & 66.182 .500 \\
\hline 6 & Juni & 5.577 .700 & 5 & 1.213 .000 & 1.254 .982 .500 & 2.500 .000 & 54.585 .000 & 57.085 .000 \\
\hline 7 & Juli & 4.331 .980 & 4 & 1.983 .500 & 974.695 .500 & 2.000 .000 & 89.257 .500 & 91.257 .500 \\
\hline 8 & Agustus & 1.657 .140 & 3 & 1.690 .000 & 372.856 .500 & 1.500 .000 & 76.050 .000 & 77.550 .000 \\
\hline 9 & September & 4.033 .400 & 2 & 1.572 .500 & 907.515 .000 & 1.000 .000 & 70.762 .500 & 71.762 .500 \\
\hline 10 & Oktober & 5.013 .620 & 5 & 1.679 .500 & 1.128 .064 .500 & 2.500 .000 & 75.577 .500 & 78.077 .500 \\
\hline 11 & November & 5.136 .580 & 3 & 1.267 .000 & 1.155 .730 .500 & 1.500 .000 & 57.015 .000 & 58.515 .000 \\
\hline \multirow[t]{3}{*}{12} & Desember & 7.720 .760 & 2 & 1.484 .500 & 1.737 .171 .000 & 1.000 .000 & 66.802 .500 & 67.802 .500 \\
\hline & Total & 52.849 .862 & 34 & 19.705 .579 & 11.891 .218 .950 & 17.000 .000 & 886.751 .055 & 903.751 .055 \\
\hline & Rata-Rata & 4.404 .155 & 2.83 & 1.642 .132 & 990.934 .913 & 1.416 .666 & 73.895 .921 & 75.312 .588 \\
\hline
\end{tabular}

Sumber : PT. Milko Beverage Industry,diolah, 2017

Tabel 4 menjelaskan mengenai jumlah biaya yang harus disediakan oleh perusahaan selama tahun 2016 yaitu Rp903.751.055,Dengan biaya pemesanan Rp17.000.000,-, penyimpanan Rp886.751.055,-. dan pembelian Rp11.891.218.950,-frekuensi pemesanan tiap bulan berbeda, disebabkan karena jumlah pembelian perpesanan berbeda sebagai akibat dari perubahanan target produski setiap bulannya. Pada bulan Maret terjadi biaya sebesar Rp101.867.500,- dikarenakan rata-rata jumlah persediaan melonjak tinggi sehingga menyebabkan tingginya biaya penyimpanan, sedangkan bulan Januari merupakan biaya terendah yaitu Rp55.583.555,- karena rendahnya pembelian dan rata-rata persediaan.

\section{Persediaan Bahan Kemasan Botol 70 ml 8 gram dengan MRP EOQ dan LFL}

MRP merupakan suatu metode dalam perencanaan serta pengendalian pesanan, dan persediaan, bersifat permintaan dependent (terikat) dan tergantung pada produk akhir (FG) atau induknya. MRP merupakan alternatif yang dapat diterapkan perusahaan dalam sistem pengendalian persediaan kebutuhan bahan kemasan, terutama dalam ukuran lot pemesanan, biaya pemesanan serta biaya untuk penyimpanan dan besarnya persediaan dan jumlah pembelian komulatif bahan kemasan. Teknik yang digunakan dalam riset ini yaitu teknik $E O Q$ dan teknik $L F L$. 1.

RP dengan Economic Order Quantity (EOQ) adalah teknik persediaan yang paling umum dikenal. Model ini mengidentifikasikan pemesanan, pembelian paling optimal yang bertujuan untuk meminimalkan nilai biaya persediaan. Ketika menggunakan teknik tersebut, perusahaan melakukan pemesanan lebih rendah/sedikit bila dibandingkan pada teknik yang dilakukan saat ini. Teknik ini dapat membuat perusahaan menekan biaya pemesanan dengan penghematan cukup besar.

$$
\begin{aligned}
& \mathrm{EOQ}=\frac{\sqrt{2 \times D \times S}}{\mathrm{H}} \\
& \mathrm{EOQ}=\frac{\sqrt{2 \times 52.387 .020 \times 500.000}}{45} \\
& \mathrm{EOQ}=1.078 .961
\end{aligned}
$$

Hasil yang diperoleh dari perhitungan menggunakan teknik MRP EOQ didapatkan hasil sebesar 1.078.961 pcs, frekuensi pembelian 47 kali pemesanan, perhitungan ditampilkan pada Tabel 5 yaitu :

\section{Tabel 5. Kebutuhan dan Biaya Metode MRP Teknik EOQ}




\begin{tabular}{|c|c|c|c|c|c|c|c|c|}
\hline $\begin{array}{l}\mathbf{N} \\
0\end{array}$ & Bulan & $\begin{array}{l}\text { Pembelian } \\
\text { (pcs) }\end{array}$ & $\begin{array}{l}\text { Frek } \\
\text { (kali) }\end{array}$ & $\begin{array}{l}\text { Persediaan } \\
\quad(P c s)\end{array}$ & $\begin{array}{c}\text { Biaya } \\
\text { Pembelian (Rp) }\end{array}$ & $\begin{array}{c}\text { Biaya } \\
\text { Pesan } \\
\text { (Rp) }\end{array}$ & $\begin{array}{l}\text { Biaya Simpan } \\
\text { (Rp) }\end{array}$ & $\begin{array}{c}\text { Total } \\
\text { Biaya(Rp) }\end{array}$ \\
\hline 1 & Januari & 4.315 .844 & 4 & 1.249 .398 & 971.064 .900 & 2.000 .000 & 56.222 .910 & 58.222 .910 \\
\hline 2 & Februari & 3.236 .883 & 3 & 1.889 .802 & 728.298 .675 & 1.500 .000 & 85.356 .090 & 86.856 .090 \\
\hline 3 & Maret & 5.394 .805 & 5 & 2.806 .349 & 1.213 .831 .125 & 2.500 .000 & 126.285 .705 & 128.785 .705 \\
\hline 4 & April & 3.236 .883 & 3 & 2.063 .253 & 728.298 .675 & 1.500 .000 & 92.846 .385 & 94.346 .385 \\
\hline 5 & Mei & 4.315 .844 & 4 & 2.513 .778 & 971.064 .900 & 2.000 .000 & 113.120 .010 & 115.120 .010 \\
\hline 6 & Juni & 4.315 .844 & 4 & 2.496 .824 & 971.064 .900 & 2.000 .000 & 112.357 .080 & 114.357 .080 \\
\hline 7 & Juli & 3.236 .883 & 3 & 3.158 .200 & 728.298 .675 & 1.500 .000 & 142.119 .000 & 143.619 .000 \\
\hline 8 & Agustus & 3.236 .883 & 3 & 1.556 .490 & 728.298 .675 & 1.500 .000 & 70.042 .050 & 71.542 .050 \\
\hline 9 & September & 3.236 .883 & 3 & 2.217 .312 & 728.298 .675 & 1.500 .000 & 99.779 .040 & 101.279 .040 \\
\hline 10 & Oktober & 5.394 .805 & 5 & 1.875 .499 & 1.213 .831 .125 & 2.500 .000 & 84.397 .455 & 86.897 .455 \\
\hline 11 & November & 6.473 .766 & 6 & 1.451 .339 & 1.456 .597 .350 & 3.000 .000 & 65.310 .255 & 68.310 .255 \\
\hline \multirow[t]{3}{*}{12} & Desember & 4.550 .539 & 4 & 2.065 .828 & 1.023 .871 .275 & 2.000 .000 & 92.962 .260 & 91.962 .260 \\
\hline & Total & 50.945 .862 & 47 & 25.351 .072 & 11.462 .818 .950 & 23.500 .000 & 1.140 .798 .240 & 1.164 .298 .240 \\
\hline & Rata-Rata & 4.245 .488 & 3.9 & 2.112 .589 & 955.234 .912 & 1.958 .333 & 95.066 .520 & 97.024 .853 \\
\hline
\end{tabular}

Sumber: Data primer diolah, 2017

Dari Tabel 5 di atas hasil hitungan $M R P-E O Q$ sehingga disimpulkan pembelian bahan kemasan sebesar 50.945.862 pcs, banyaknya pemesanan (frekuensi) sebanyak 47 kali pesan, total persediaan sebanyak 25.351.072 pcs, biaya pembelian sebesar Rp11.462.818.950,biaya pemesanan sebesar Rp23.500.000,biaya untuk penyimpanan sebesar Rp1.140.798.240, sehingga total biaya sebesar Rp1.164.298.240,-. Jumlah biaya paling besar terdapat pada bulan Juli yaitu sebesar Rp143.619.000,- Hal tersebut disebabkan tingginya persediaan yaitu sebanyak 3.158.200 pcs sehingga menyebabkan besarnya biaya penyimpanan pada bulan tersebut. Sedangkan total biaya terkecil terjadi pada bulan Januari sebesar Rp58.222.910,- hal tersebut terjadi dikarenakan persediaan yang kecil yaitu sebesar 1.249 .398 pcs dibandingkan dengan persediaan pada bulan lainnya, sehingga biaya simpan juga paling kecil yaitu sebesar Rp56.222.910,dibandingkan dengan bulan yang lainnya. Perhitungan MRP menggunakan teknik $E O Q$ jika dikomparasikan dengan perhitungan perusahaan maka memiliki hasil lebih besar dengan selisih perhitungan sebesar Rp260.547.185,- atau sebesar 22,38 persen apabila dibandingkan dengan hasil perhitungan perusahaan.

2. MRP dengan Lot-For-Lot (LFL). Teknik $L F L$ merupakan teknik penentuan untuk ukuran lot, memesan kuantitas sesuai kebutuhan, tanpa persediaan buffer stock dan tidak adanya perhitungan atas pesanan yang lebih lanjut, metode ini perlu diterapkan secara konsistensi pada ukuran jumlah lot kecil, pesanan setiap berkala, persediaan on hand rendah dan permintaan terkait. Teknik ini memungkinkan penekankan biaya penyimpanan hingga nol atas persediaan yang disimpan. Berikut biaya persediaan menggunakan metode $M R P-L F L$ pada Tabel 6:

Tabel 6. Kebutuhan dan Biaya Metode MRP Teknik LFL 


\begin{tabular}{clccccccc}
\hline No & Bulan & $\begin{array}{c}\text { Pembelian } \\
(\text { pcs })\end{array}$ & $\begin{array}{c}\text { Frek } \\
\text { (kali) }\end{array}$ & $\begin{array}{l}\text { Persediaa } \\
\text { n(pcs) }\end{array}$ & $\begin{array}{c}\text { Biaya Pembelian } \\
\text { (Rp) }\end{array}$ & $\begin{array}{c}\text { Biaya } \\
\text { Pemesanan } \\
\text { (Rp) }\end{array}$ & $\begin{array}{c}\text { Biaya } \\
\text { Penyimpanan( } \\
\text { Rp) }\end{array}$ & $\begin{array}{c}\text { Total Biaya } \\
\text { (Rp) }\end{array}$ \\
\hline 1 & Januari & 3.740 .907 & 4 & 342.258 & 841.704 .075 & 2.000 .000 & 15.401 .610 & 17.401 .610 \\
2 & Februari & 3.630 .795 & 4 & - & 816.928 .875 & 2.000 .000 & - & 2.000 .000 \\
3 & Maret & 4.636 .215 & 4 & - & 1.043 .148 .375 & 2.000 .000 & - & 2.000 .000 \\
4 & April & 3.546 .225 & 4 & - & 797.900 .625 & 2.000 .000 & - & 2.000 .000 \\
5 & Mei & 4.320 .465 & 4 & - & 972.104 .625 & 2.000 .000 & - & 2.000 .000 \\
6 & Juni & 4.252 .020 & 4 & - & 956.704 .500 & 2.000 .000 & - & 2.000 .000 \\
7 & Juli & 3.668 .520 & 4 & - & 825.417 .000 & 2.000 .000 & - & 2.000 .000 \\
8 & Agustus & 2.744 .955 & 4 & - & 617.614 .875 & 2.000 .000 & - & 2.000 .000 \\
9 & September & 3.907 .455 & 4 & - & 879.177 .375 & 2.000 .000 & - & 2.000 .000 \\
10 & Oktober & 5.461 .110 & 4 & - & 1.228 .749 .750 & 2.000 .000 & - & 2.000 .000 \\
11 & November & 5.875 .875 & 4 & - & 1.322 .071 .875 & 2.000 .000 & - & 2.000 .000 \\
12 & Desember & 5.161 .320 & 3 & - & 1.161 .297 .00 & 1.500 .000 & - & 2.000 .000 \\
\hline & Total & 50.945 .862 & 47 & 342.258 & 11.462 .818 .950 & 23.500 .000 & 15.401 .610 & 38.901 .610
\end{tabular}

Sumber: Data primer diolah, 2017

Tabel 6 di atas menjelaskan perhitungan metode $M R P$ teknik $L F L$ sehingga disimpulkan bahwa pembelian bahan kemasan 50.945 .000 pcs, pemesanan (frekuensi) 47 kali, total persediaan sebanyak 342.258 pcs, biaya pembelian Rp11.462.818.000,- biaya pemesanan Rp23.500.000,- biaya penyimpanan Rp15.401.610,- dengan jumlah biaya Rp38.901.000,-. Biaya pesanan sama setiap bulannya terkecuali bulan Desember terjadi perbedaan frekuensi pemesanan. Biaya pemesanan hampir nol diakibatkan persediaan yang tersedia seminimum mungkin atau hampir mendekati nol kecuali bulan Januari yang masih ada sisa dari persediaan.
Perhitungan MRP teknik LFL dibandingkan dengan perusahaan memiliki hasil paling minimum yaitu selisihnya sebesar Rp 864.849.445,- atau sebesar 95,69 persen dibandingkan dengan hasil perhitungan perusahaan.

\section{Perbandingan Metode Pengendalian Persediaan}

Berdasarkan hasil perhitungan yang diperoleh antara pengendalian persediaan perusahaan dengan metode Material Requirement Planning (MRP) dengan teknik Economic Order Quantity (EOQ) dan Lot For Lot (LFL), selama periode bulan JanuariDesember 2016, dapat dilakukan perbandingan antara teknik-teknik tersebut. Berikut perbandingan perhitungan disajikan dalam Tabel 7:

\section{Tabel 7. Perbandingan Perhitungan Perusahaan dengan Metode MRP EOQ dan LFL}

\begin{tabular}{lccccrr}
\hline Metode & $\begin{array}{c}\text { Frekuensi } \\
(\text { kali })\end{array}$ & $\begin{array}{c}\text { Jumlah } \\
\text { Pembelian } \\
(p c s)\end{array}$ & $\begin{array}{c}\text { Biaya } \\
\text { pembelian } \\
(\mathrm{Rp})\end{array}$ & $\begin{array}{c}\text { Biaya } \\
\text { Pemesanan } \\
(\mathrm{Rp})\end{array}$ & $\begin{array}{c}\text { Biaya } \\
\text { Penyimpanan } \\
(\mathrm{Rp})\end{array}$ & $\begin{array}{c}\text { Total Cost } \\
(\mathrm{Rp})\end{array}$ \\
\hline Perusahaan & 34 & 52.849 .862 & 11.891 .218 .950 & 17.000 .000 & 886.751 .055 & 903.751 .055 \\
\hline EOQ & 47 & 50.945 .862 & 11.462 .818 .950 & 23.500 .000 & 1.140 .798 .240 & 1.164 .298 .240 \\
\hline LFL & 47 & 50.945 .862 & 11.462 .818 .950 & 23.500 .000 & 15.401 .610 & 38.901 .610 \\
\hline
\end{tabular}

Sumber: Data primer diolah, 2017

Berdasarkan Tabel 7 di atas, hasil pembelian 34 kali, jumlah 52.849.000 pcs, hitungan perusahaan melakukan frekuensi biaya Rp11.891.218.000-, 
dengan jumah biaya pesanan dan penyimpanan Rp903.751.000,- . Metode $M R P$ $E O Q$ pembelian $47 \mathrm{kali}$, jumlah 50.945 .000 pcs, biaya Rp11.462.828.000,- dengan jumlah biaya pesanan dan penyimpanan Rp1.164.298.000-. Metode MRP- LFL pembelian 47 kali, jumlah 50.945.000 pcs, biaya Rp11.464.818.000,- dengan jumlah biaya pesanan dan penyimpanan Rp38.901.000,-.

Hasil yang diperoleh dari perhitungan metode MRP-LFL, memberikan suatu alternatif untuk perusahaan dalam menghasilkan biaya penghematan pada penyimpanan dan pemesanan. Hasil ini diperkuat oleh penelitian sebelumnya yang dilakukan oleh Achmad Sumbaryadi (2010) dalam penelitiannya yang berjudul Perhitungan biaya persediaan bahan baku di PT. Fajar Plasindo, dengan alternatif metode yaitu Lot For Lot (LFL), Economic Order Quantity (EOQ), Least Total Cost (LTC) dan Least Unit Cost (LUC) diperoleh hasil rekomendasi bagi perusahaan dengan menggunakan lot sizing $L F L$ dan Metode $L U C$ karena memberikan biaya paling kecil. Sedangkan menurut Amirul Ihwan (2016) dalam penelitiannya diperoleh hasil perencanaan material tepat bagi perusahaan. Hasil dari analisa metode MRP dengan menggunakan EOQ, POQ, dan LFL direkomendasikan teknik lot sizing yang lebih efisien adalah Lot For Lot (LFL).

Menurut Herjanto (2008), kebutuhan persediaan yang diketahui besarnya dan seragam dari suatu periode ke periode lain, ukuran lot optimal dapat dicari menggunakan metode $E O Q$. Namun, bagi permintaan tidak seragam atau bervariasi, metode $E O Q$ sering kali tidak memberikan hasil optimal

Dampak Perubahan Harga Terhadap Optimalisasi Pengendalian Persediaan Bahan Kemasan Botol $70 \mathrm{ml} 8$ gram di PT. Milko Beverage Industry
Analisis Sensitivitas

Analisis sensitivitas adalah analisis yang digunakan sebagai solusi yang paling dianggap optimal, yang terjadi karena perubahan lingkungan, peraturan, kebijakan pemerintah, dan lain-lain. Harga bahan kemasan periode 1 tahun bersifat konstan, tetapi dalam kenyataannya harga tersebut bisa mengalami kenaikan dan penurunan harga akibat dari mahalnya bahan kemasan tersebut (biji plastik marlek HDPE). Analisis senstivitas ini menganalisis perubahan dari inflasi Bank Indonesia selama periode tahun 2016, yaitu sebesar 3.53 persen, perubahan hasil metode MRP-LFL ditampilkan pada Tabel 8 berikut :

Tabel 8. Perhitungan Metode MRP Teknik LFL Terhadap Perubahan Harga

\begin{tabular}{cccc}
\hline Metode & $\begin{array}{c}\text { Total Cost Sebelum } \\
\text { Kenaikan }(\mathrm{Rp})\end{array}$ & $\begin{array}{c}\text { Total Cost Setelah } \\
\text { Kenaikan }(\mathrm{Rp})\end{array}$ & $\begin{array}{c}\text { Kenaikan Total } \\
\text { Cost }(\%)\end{array}$ \\
\hline IIRP & 38.901 .610 & 40.415 .676 & $3.8 \%$ \\
LFL & & & \\
\hline
\end{tabular}

Sumber: Data primer diolah, 2017

Berdasarkan Tabel 8 terlihat bahwa perhitungan menggunakan metode $L F L$ mengalami kenaikan biaya sebesar 3,8 persen, hal ini karena terjadinya inflasi dari Bank Indonesia sebesar 3,53 persen. Kenaikan perubahan biaya ini berada dibawah standar perusahaan yang memberikan kebijakan kenaikan biaya maksimal dengan kenaikan sebesar 5 (lima) persen.

Hasil perhitungan menggunakan analisis sensitivitas dan dengan adanya kebijakan dari perusahaaan, bahwa metode $M R P-L F L$ dapat digunakan perusahaan saat ini dan dapat digunakan kembali untuk periode mendatang.

\section{SIMPULAN DAN IMPLIKASI}

Berdasarkan hasil pembahasan di atas, maka disimpulkan sebagai berikut:

1. Sistem pengendalian pada persediaan bahan kemasan botol ukuran $70 \mathrm{ml} 8$ gram di 
perusahaan menggunakan FIFO (First InFirst Out) dengan pembelian berdasarkan target produksi.

2. Hasil perhitungan MRP dengan Lot fot Lot ( $L F L$ ) lebih hemat 95 persen dibandingkan dengan perhitungan perusahaan dan $M R P$ dengan $E O Q$. Sehingga direkomendasikan untuk digunakan oleh perusahaan .

3. Perhitungan analisis sensitivitas untuk metode $M R P$ dengan $L F L$ terhadap dampak inflasi Bank Indonesia terjadi kenaikan sebesar 3,8\% dan berada dibawah standar kebijakan perusahaan maksimum $5 \%$

Berdasarkan hasil analisis metode dengan perhitungan metode $M R P$, maka implikasinya:

1. Hasil analisis dan perhitungan metode $M R P$ LFL memberikan solusi alternatif terbaru untuk perusahaan dalam meminimalisasi biaya penyimpanan dan biaya pembelian persediaan. Metode $M R P-L F L$ diusulkan penerapannya pada perusahaan dengan beberapa langkah yang harus diterapkan: 1) Terjalinnya kerjasama perusahaan dengan supplier botol; 2) Diadakannya kontrak perusahaan dengan supplier; 3) Supplier bersedia melakukan buffer stock untuk botol tersebut di gudang supplier; 4) Bila ada permintaan yang meningkat secara mendadak, supplier bersedia untuk langsung mengirimkan botol tersebut.

2. Perusahaan perlu memperhatikan keakuratan pembelian dan kebutuhan akan persediaan bahan kemasan yang optimal sesuai keadaan produksi dan kondisi perusahaan.

3. Melakukan pesanan ulang bahan kemasan botol sesuai dengan rata-rata pemakaian produksi, sehingga tidak terjadinya kelebihan persediaan, sehingga menghemat biaya seminimal mungkin.

\section{UCAPAN TERIMA KASIH}

Ucapan terima kasih kepada manajemen PT. Milko Beverage Industry Bogor.

\section{DAFTAR PUSAKA}

Achmad Sumaryadi, 2010. Penerapan Metode Material Requirement Planning Untuk Meminimumkan Biaya Persediaan Bahan Baku pada PT. Fajar Plasindo. Paradigma Vol XII. No. 2 September, 2010.

Adisaputro, G dan Yunita A. 2007. Anggaran

Bisnis: Analisa Perencanaan dan Pengendalian Laba. Yogyakarta. UPP Stim Ykpn.

Anisa Ariesty, Titiek Tjahya Andari, 2015, Metode Economic Quantity Interval untuk Optimalisasi Persediaan Barang Consumable Adem Sari Pada PT. Sari Enesis. Bogor. Jurnal Visionida Vol 2 No 1 Juni 2016,

Amirul Ihwan, Suhartini, 2016. Pengendalian Persediaan Bahan Baku Springbed Metode Material Requirement Planning Studi Kasus di PT. XYZ. ISBN978-602-98569-10 .

Arminas, Neno Ikranegara, 2015. Pengendalian Persediaan Bahan Baku Dengan Metode Material Requirement Planning (MRP) Pada Usaha Dagang (UD) Mitra Usaha Kayu Di Kabupaten Enrekang. Makasar. Seminar Nasional IENACO-2015. ISSN:2337-4349.

Assauri, Sofyan. 2004. Manajemen Produksi dan Operasi. BPFE Universitas Indonesia. Jakarta.

Assauri, Sofyan. 2008. Manajemen Produksi dan Operasi. Jakarta. BPFE Universitas Indonesia.

Asvin Wahyuni, Achmad Syaichu, 2015. Perencanaan Persediaan Bahan Baku Dengan Menggunakan Metode MaterialRequiremenet Planning (MRP) Produk Kacang Shanghai Pada Perusahaan Gangsar Ngunut Tulung Agung. Jawa Timur. Jurnal Spektrum Industri Vol. 13, No.2, 115-228, ISSN 2936590.

Baroto, Teguh. 2002. Perencanaan dan Pengendalian Produksi. Jakarta. Ghalia Indonesia. 
Data Inflasi Bank Indonesia, 2016, (online), (www.BankIndonesia.go.id diakses 05 Januari 2018)

Dhanang Eka Putra, 2008. Analis Persediaan Bahan Baku Kulit pada PT Mastoro Indonesia (Kawasan Industrial Sentul, Bogor, Jawa Barat). Bogor. Skripsi Sarjana, Institut Pertanian Bogor,

Ginting, Rosnani. 2007. Yogyakarta. Sistem Ptroduksi. Graha Ilmu.

Handoko, T. Hani. 2011. Dasar-Dasar Manajemen Produksi dan Operasi. Yogyakarta. BPFE.

Haryono, Siswoyo. 2000. Manajemen Produksi dan Operasi. Jakarta. Lembaga Bisnis dan Majanemen Global.

Heizer, Jay dan Barry Render. 2010. Manajemen Operasi. Jakarta. Edisi 9. Salemba Empat.

Herjanto, Eddy. 2008. Manajemen Produksi dan Operasi. Yogyakarta. BPFE.

Klimchuk. Marianne dan Sandra A. Krasovec. 2006. Desain Kemasan. Jakarta. Erlangga.

Kotler dan Keller. 2009. Manajemen Pemasaran. Jakarta. Jilid I edisi ke 13. Erlangga.

Juliana, 2016, Analisa Pengendalian Persediaan Pada Proyek Pembangunan Line Conveyor Untuk Meminimalisasikan Biaya Persediaan. Jurnal String Vol 1 No. 1 Tahun 2016, ISSN: 2527-9661.

Januwar Candra, 2014 Analisa Penjadwalan Persediaan Timbangan Model SM 5600 Dengan Metode Lot For Lot Studi Kasus di PT Tropical Electronic Batam. Jurnal Profesiensi, 2(2):122-131 Desember 2014, ISSN2301-7244.

Margareth, Farah. 2004. Teori dan Aplikasi Manajemen Keuangan. Jakarta. PT Gramedia Widisarana Indonesia.

Muhammad Ihsanudin, 2015, Simulasi Metode Pengendalian Persediaan (Studi Kasus di Restoran " Sweet Corner" Hotel Atlet Century Park Jakarta). Jakarta. Skripsi Sarjana, Program Studi Agribisnis, Fakultas Sain dan Teknologi, Universitas Islam Negeri (UIN) Syarif Hidayatullah.
Muzayyanah, I ketut Suamba, Ratna Komala Dewi. Analisis Pengendalian Persediaan Bahan Baku Biji Kakao Pada Pabrik Delicacao Bali di Kabupaten Tabanan. Bali. Jurnal Agribisnis dan AgrowisataVo.4, No.4 Oktober 2015.

Nugroho, Bernadus Y. Saragih, Ferdinand D. Dan Eko Umanto. 2012. Metode kuantitatif. Jakarta. Edisi 2. Salemba Humanika.

Pranoto, Djoko. 2011. Manajemen Persediaan. Jakarta. Grasindo.

Prawirosentono, Suryadi. 2000. Manajemen Operasi. Jakarta. Bumi Aksara.

Rangkuti, Freddy. 2007. Manajemen Persediaan. Raja Grafindo Persada.

Richardus E. Indrajit dan Djokopranoto Richardus. 2005. Strategi Manajemen Pembelian dan Supply Chain. Jakarta. Grasindo.

Rosmiati, Rustam Abdul Rauf, Dafina Howara. 2013, Analisa Economic Order Quantity Untuk Menentukan Persediaan bahan Baku Keripik Sukun (Studi Kasus Industri Rumah Tangga Citra Lestari Production). Palu. EJurnal Agrotekbis 1 (1) : 93-99, ISSN: 23383011 .

Shihah Khoirunnisa, Nuriyanto, 2014, Analisa Pengendalian Persediaan Bahan BakuMidsole Pada Insdustri Sepatu Menggunakan Metode Economic Order Quantity.Pasuruan. Jurnal Yudharta P-ISSN : 2460-01131 E-ISSN : 2541-4461.

Sugiyono. 2009, Metode Penelitian Bisnis. Bandung. CV Alfabeta.

Tampubolon, Manahan P. 2004. Manajemen Operasional. Jakarta. Ghalia Indonesia.

Tersine, Richard J.1994. Principles Of Inventory and Materials Management. Fourth Edition. Prentice-Hall,Inc, New York 